\title{
自己組織多孔膜のナノ秒パルスレーザー照射による構造制御
}

\author{
松村行真 ${ }^{1}$, 居波 涉 ${ }^{2,3}$, 川田 善正 ${ }^{1,3}$ \\ 1静岡大学創造科学技術大学院（７432-8561 静岡県浜松市中区城北3-5-1） \\ 2静岡大学 若手グローバルリーダー育成拠点 ( ₹432-8561 静岡県浜松市中区城北3-5-1) \\ 3科学技術振興機構CREST (†102-0075 東京都千代田区三番町5)
}

\section{Control of Self-Organization Microporous Structure by The Laser Irradiation}

\author{
Yukimasa MATSUMURA, ${ }^{1}$ Wataru INAMI, ${ }^{2,3}$ and Yoshimasa KAWATA ${ }^{1,3}$ \\ ${ }^{1}$ Graduate School of Science and Technology, Shizuoka University, 3-5-1 Johoku, Naka-ku, Hamamatsu, Shizuoka 432-8561 \\ ${ }^{2}$ Division of Global Research Leaders, Shizuoka University, 3-5-1 Johoku, Naka-ku, Hamamatsu, Shizuoka 432-8561 \\ ${ }^{3}$ JST-CREST, 5 Sambancho, Chiyoda-ku, Tokyo 103-0075
}

(Received October 21, 2010)

\begin{abstract}
We have developed a technique that uses laser irradiation to control microporous structures during selforganization processes. A polymer solution is dropped on a substrate in high humidity conditions and a honeycomb structure of regularly aligned pores on the film is fabricated by attaching water droplets to the solution surface. We demonstrate that it is possible to prevent pores forming in the laser irradiated area and that a flat surface and small pores can be fabricated. This microfabrication processing technique combines the advantages of bottom-up and top-down techniques. This method is expected to be applicable to fabricating photonic crystals and culturing biological cells and to surface science and electronic applications.
\end{abstract}

Key Words: Laser processing, Microfabrication, Self-organization, Microporous honeycomb film

1.はじめに

超微細加工技術の需要とともに, ナノ構造を作製する ための多くの手法が提案, 開発されてきた ${ }^{1)}$ 。微細加工 は，トップダウン方式とボトムアップ方式の二つに分類 することができる。トップダウン方式としてフォトリソ グラフィがよく知られており, 高精度な加工を高い再現 性で実現できるという特徵を有する。しかし，一般的に 高価な装置を必要とし, 多くの工程を行い加工時間が長 くなるという欠点を有する2).

一方，ボトムアップ方式としては自己組織化が知られ ている. ボトムアップ方式の利点は低コストでかつ加工 時間も短く，規則的な構造を大面積に作製できるという 点が挙げられる。しかし，一部分のみを任意の構造にす ることは困難である。

我々は，自己組織化プロセスで規則的な構造を作製す る過程においてレーザー光を照射し，自己組織化を制御 する手法を提案する。自己組織化過程のレーザー制御が 実現できれば，規則的な周期構造の中に，任意の構造を 作り込むことが可能となる。

本研究に扮ける自己組織化プロセスには，水支援成形 高分子溶液キャスティング法を用いる。本手法は, 高湿 度大気下で基板上に高分子溶液を滴下することで多孔構 造薄膜を作製する手法である ${ }^{3-13)}$ 。この技術を用いて，
フォトニック結晶や細胞培養基板, 超撥水性素材, フィールドエミッタ等への応用の研究がなされてき た ${ }^{14-26)}$ ，我々の手法により多孔構造を制御し，応用範囲 の広い高機能多孔薄膜を作製することが可能になるもの と考える.

\section{2. 自己組織プロセスのレーザー制御}

\section{1 自己組織多孔膜の作製}

自己組織プロセスを用いてハニカム多孔構造高分子薄 膜を作製する手法の原理および作製手順を以下に説明す る3．揮発性の高い有機溶媒に，親水基を備えたポリ マーを溶解させ，この溶液を高湿度大気下でガラス基板 に滴下する。溶媒が蒸発するのに伴い，溶液表面近傍の 空気は気化熱により冷却される。溶液表面が冷却された ことにより，水滴が溶液表面に結露して付着する。これ らの水滴は，溶液表面の泠却により発生した液滴内部の 対流により，一部が液滴内部に侵入する。溶液表面の水 滴は，溶液の三相界面 (溶液 - 基板 - 空気の界面)に向 かって作用する毛管力によりハニカム状の配列にパッキ ングされる。溶媒と水滴が完全に蒸発すると，溶液表面 に存在していた水滴の部分が孔となり，規則的に配列し たハニカム多孔構造を自己組織化により得ることができ る. 
我々は, 親水基としてカルボキシル基を端部に備えた ポリスチレン (Mw：50,000, Scientific Polymer Products, Inc.製)をクロロホルム (関東化学 (株) 製)に溶解させ た。この溶液を，相対湿度を75\%に制御した状態でカ バーグラス $(24 \mathrm{~mm} \times 40 \mathrm{~mm}$ ，松浪硝子工業(株)製)に滴 下した。これにより得られた自己組織高分子多孔膜は走 査型電子顕微鏡 $(S E M$; JSM-6390, JEOL)にて観察を行 なった。

\section{2 自己組織プロセスのレーザー制御}

Fig. 1に自己組織多孔膜作成過程をレーザー照射によ り制御した光学系を示す。光源にはQ-switched Nd:YAG レーザー(波長： $532 \mathrm{~nm}$ ，パルス幅：3-5 ns，繰り返し 周波数：1-15 Hz) を用いた。倍率20倍, 開口数 0.40 の対 物レンズによりカバーグラス上の溶液にレーザーを集光 させた。自己組織化プロセスにおいて溶液厚さは溶媒の 蒸発と共に減少していくため, CCDカメラで溶液表面 の観察を行いながら，カバーグラスのを光軸方向にス テージを操作して移動させた。自己組織化プロセス完了 直前にレーザー光を1パルス照射した。

\section{3. 自己組織化のレーザー制御結果及び考察}

\subsection{1 パルス照射による多孔構造制御}

Fig. 2にレーザー照射により自己組織化を制御して得 られた高分子薄膜のSEM画像を示すＦig. 2 (a) にレー ザーを照射した領域の全体像を示し，Fig. 2 (b) に自己 組織化による多孔構造とレーザー照射による平面構造の 境界部分の拡大像を示す。レーザー照射により水滴が取 り除かれ，平面構造となった領域を得ることができた。 この実験ではカバーグラスに溶液を滴下してから53秒後 にレーザーを溶液表面に照射した。溶液濃度は $40 \mathrm{~g} / \mathrm{L}$,

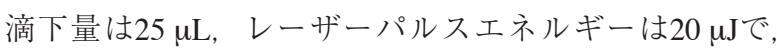
1パルスレーザー照射を行なった。

自己組織化プロセスにおいて水滴が付着し多孔構造を 形成している過程にレーザーを照射することで，レー ザー光の照射領域から, 水滴を除去し多孔構造と平面 構造の共存した高分子薄膜を得ることができる。

Fig. 2 (c)に53秒よりも早くレーザー照射した場合，ま

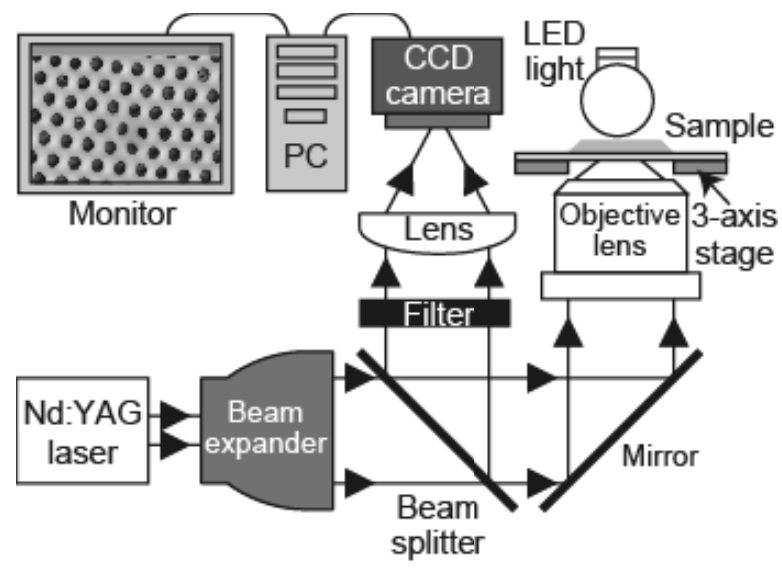

Fig. 1 Self-organization control optical setup.

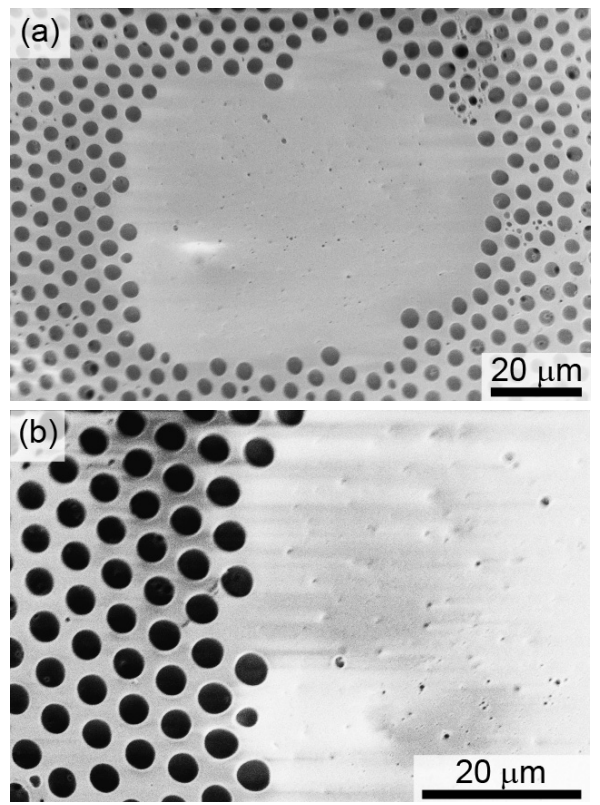

(c)
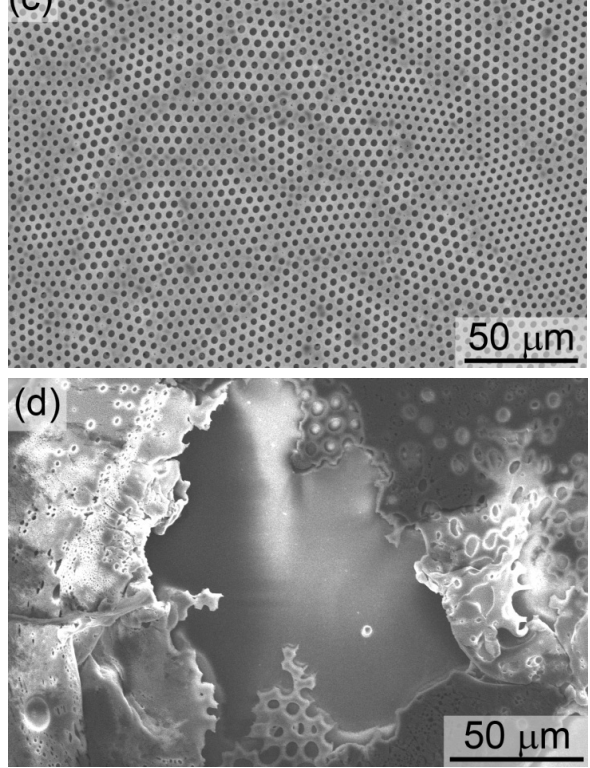

Fig. 2 SEM images of self-organization control microporous polystyrene film by laser irradiation (a) entire picture, (b) magnified picture, (c) microporous film because of early irradiation of laser pulse, and (d) broken film because of later irradiation of laser pulse.

たFig. 2 (d)に53秒よりも遅くレーザー照射した場合の 結果を示す。レーザーを照射するタイミングが早すぎる と，照射した領域の水滴を取り除いても，毛管力のはた らきにより周囲からの水滴で覆われてしまい, 平面構造 を得ることはできない。また，タイミングが遅い場合に は，自己組織化が完了してしまい，得られた多孔構造を レーザー照射により破壊してしまうこととなる。

\section{2 レーザー照射による照射部の温度上昇}

レーザー照射により水滴が除去される原理について考 察するため，レーザー照射部の温度上昇を検討した。

物体に一様なパワーのレーザーを照射した際に，その 
物体がレーザー光を吸収したときの温度上昇は,

$$
\begin{aligned}
& T= \\
& \frac{2 P}{\pi a^{2}} \cdot \frac{\sqrt{k t}}{K}\left[\frac{1}{\sqrt{\pi}}-\left\{\frac{1}{\pi} e^{-\frac{\alpha^{2}}{2 \sqrt{k t}}}-\frac{a^{2}}{2 \sqrt{k t}}\left(1-\frac{2}{\sqrt{\pi}} \int_{0}^{\frac{a^{2}}{2 \sqrt{k t}}} e^{-x^{2}} d x\right)\right\}\right]
\end{aligned}
$$

で表される27)。ここで， $P$ ：吸収されたレーザーパワー $[\mathrm{W}], k$ : 熱拡散率 $\left[\mathrm{m}^{2} / \mathrm{s}\right], K$ : 熱伝導率 $[\mathrm{W} /(\mathrm{m} \cdot \mathrm{K})]$, $t:$ レーザー照射時間 $[\mathrm{s}], a$ : ビーム半径 $[\mathrm{m}]$ である。ま た，吸収されたレーザーパワーは

$$
P=\frac{P_{0}}{t}\left(1-e^{-\alpha l}\right)
$$

で表される ${ }^{28)}$.ここで, $P_{0}:$ レーザーパルスエネルギー $[\mathrm{J}], \alpha$ : 吸収係数 $[1 / \mathrm{m}], l:$ レーザー透過距離 $[\mathrm{m}]$ であ る。実験条件より，照射したレーザーパルスエネルギー は20 $\mu \mathrm{J}$ ，照射時間はパルス幅の $5 \mathrm{~ns}$ とる。また波長 $530 \mathrm{~nm}$ のとき, 純水の吸収係数は $4.2 \times 10^{-6} \mathrm{~m}^{-1}$ であり, レーザー透過距離は集光した際の焦点深度とする ${ }^{28)}$. 理 論的に取りうる最大の温度上昇として, シングルモード ビームが理想的に集光された場合の值を用いると，開口 数 0.40 のレンズで, 波長 $532 \mathrm{~nm}$ のレーザーを集光した際 の焦点深度は3.3 um, 同様にレーザービーム半径は $0.81 \mu \mathrm{m}$ と仮定できる。 これらの值を式(2)に代入すると, 吸収されたレーザーパワーは $5.6 \times 10^{-8} \mathrm{~W}$ なる。純水 の熱拡散率および熱伝導率はそれぞれ $1.4 \times 10^{-4} \mathrm{~m}^{2} / \mathrm{s}$, $593 \mathrm{~W} /(\mathrm{m} \cdot \mathrm{K})$ である ${ }^{29)}$. 以上の值を(1) 式に代入する と，レーザー照射部の温度上昇は $1.9 \times 10^{-5} \mathrm{~K}$ となる。 以上のことから，自己組織化プロセスにおけるレーザー 照射による構造制御では, 熱による水滴の蒸発が主な要 因ではないと結論できる。

\section{3 レーザー照射衝撃波による水滴除去}

3.2で議論したように，レーザー光の吸収による熱の 上昇がほとんどないことから, 我々は水滴除去の主な要 因をナノ秒パルス光の照射によるアブレーション圧力に よるものであると考えている。レーザー集光におけるア ブレーション圧力は

$$
P_{a}=0.86\left(\frac{I}{\lambda}\right)^{\frac{2}{3}}
$$

で表される ${ }^{30)}$ 。ここで，I：吸収されたレーザー光強度

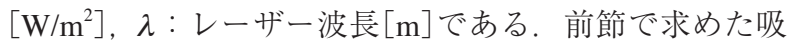
収されたレーザーパワーおよびレーザースポットより, 吸収されたレーザー光強度を $2.7 \mathrm{~W} / \mathrm{cm}^{2}$ と仮定する。波 長は532 nmであるので，これらの值を式(3)に代入する と, レーザー照射によるアブレーション圧力は $12 \mathrm{MPa}$ である，集光部にてレーザーアブレーション誘起による 衝撃波が発生したと考える.クロロホルムの表面張力は
$27.1 \mathrm{mN} / \mathrm{m}$ である゙.レーザー集光部から発生する力は レーザーアブレーション圧力とレーザースポットの円周 長から $61 \mathrm{~N} / \mathrm{m}$ と仮定でき，水滴が周囲より押し寄せる 力を上回り，照射部の水滴を取り除いたと考える.

Fig. 3にレーザーアブレーション誘起の衝撃波による自 己組織化プロセス制御の模式図を示す。溶媒の蒸発が完 了する直前にレーザーパルスを照射することで，照射し た部分に再び水滴が付着する時間がないため水滴が取り 除かれた平面な部分が多孔構造中に作製することができ る.

\section{4 液滴内部の集光による孔径の制御}

我々は，レーザーの集光位置を溶液表面ではなく，溶 液内部に集光することにより, 多孔構造の孔径を制御す ることに成功した. Fig. 4に, 液滴内部レーザー集光に より微細な多孔構造を得られたSEM画像を示す。画像 右側がレーザー照射により, 周囲に比べて微細な多孔構 造を得られた領域である。集光位置を溶液表面から液滴 内部, 溶液表面から約 $30 \mu \mathrm{m}$ 内部に変更しレーザー照射 を行なった。この実験ではカバーグラスに溶液を滴下 してから120秒後にレーザーを照射した。溶液濃度は

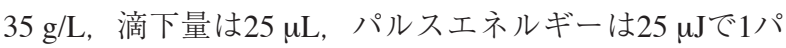
ルスのみの照射を行なった。レーザーを照射した領域は 孔径が $1.6 \mu \mathrm{m}$ ，孔の中心間距離が $2.8 \mu \mathrm{m}$ であり，レー ザー照射の周辺の領域は孔径が $4.4 \mu \mathrm{m}$ ，孔の中心間距離

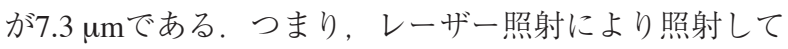

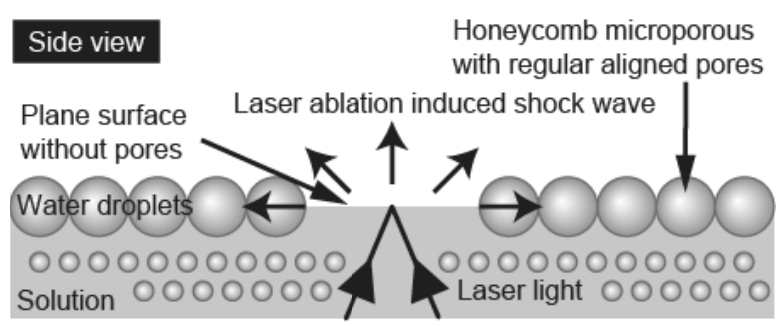

Fig. 3 Side view pattern diagram of solution surface with laser irradiation.

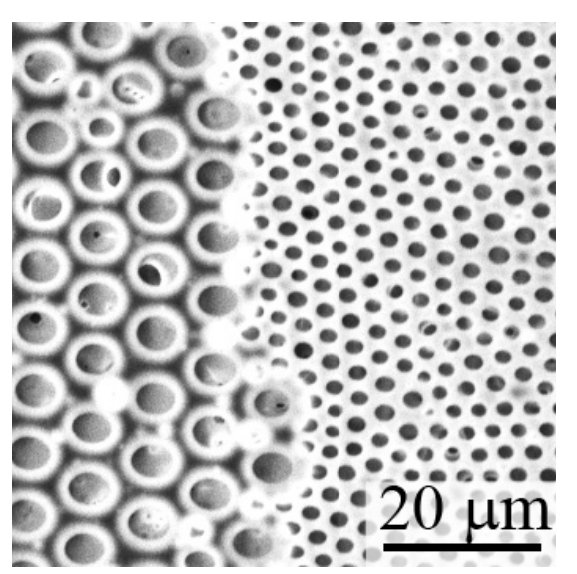

Fig. 4 SEM image of fine microporous polystyrene film by laser irradiation self-organization control.

†信越化学工業(株)HP「“信越クロロホルム”製品情報」 


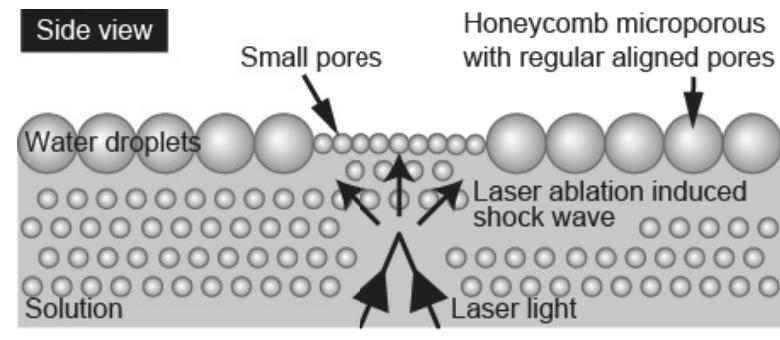

Fig. 5 Side view pattern diagram of inner laser focus of solution droplet.

いない領域に比べて約3分の1の大きさへと制御すること ができた。

我々は，溶液内部ヘレーザーを集光することにより孔 径を制御できる理由を, 溶液内部の水滴がレーザー照射 により表面に移動したためと考えている. Fig. 5に滴下 溶液内部に集光した際の, 微小水滴浮上による微細多孔 構造作製の模式図を示す。自己組織化過程において，ガ ラス基板に溶液を滴下し, 溶媒の蒸発により液滴表面の 温度は下がり, 結露により発生した水滴が溶液表面に付 着する，溶液表面の温度が下がったため，液滴内部にて 対流が発生し, 溶液表面の一部の水滴は液滴内部に侵入 する，液滴表面の水滴は，空気中から水分が供給される ため, 時間と共に水滴の大きさは大きくなる。一方, 液 滴内部に侵入した水滴は大きさが成長することなく孔径 が小さい状態である。そのため, 自己組織化完了直前に 溶液内部にレーザーを集光することで，レーザーアブ レーション誘起による衝撃波が発生し, 集光位置の前方 に向かって作用する力と共に, 液滴表面に微小水滴が浮 上したと考える。その微細な状態のまま自己組織化が完 了し，レーザーを照射した周囲よりも微細な孔構造を得 ることができたと考える。

\section{4. まとめ}

我々は自己組織化プロセスにおいてレーザーを照射す ることで微細多孔構造の制御が可能であることを示し た。滴下した溶液表面にレーザーを集光することで, レーザーアブレーション誘起の衝撃波を発生させ, 多孔 構造中に平面構造を作製することができた。また，滴下 溶液内部にレーザーを集光することで, 液滴内部の微小 水滴を浮上させ，レーザーを照射した周囲よりも微細な 多孔構造を作製することができた。これらの構造は，自 己組織化プロセスだけでは作製することができず，本手 法のボトムアップ手法とトップダウン手法の融合による ものである。本技術により得られた薄膜はフォトニック 結晶, バイオテクノロジー分野, 超撥水性素材, エレク トロニクス分野等への応用が期待できる.

\section{参考文献}

1) M. Madou: Fundamental of Microfabrication (CRC Press LLC, 1997).

2) 川合知二：図解ナノテクノロジーのすべて(工業調査会, 2002).

3) G. Widawaski, M. Rawiso, and B. Francois: Nature 369 (1994) 387.

4) N. Maruyama, T. Koito, J. Nishida, T. Sawadaishi, X. Cieren, K. Ijiro, O. Karthaus, and M. Shimomura: Thin Solid Films 327-329 (1998) 854.

5) B. de Boer, U. Stalmach, H. Nijland, and G. Hadziioannou: Advanced Materials 12 (2000) 1581.

6) M. H. Stenzel-Rosenbaum, T. P. Davis, A. G. Fane, and V. Chen: Angewandte Chemie 113 (2001) 3428.

7) M. Srinivasarao, D. Collings, A. Philips, and S. Patel: Science 292 (2001) 79.

8) L. Song, R. K. Bly, J. N. Wilson, S. Bakbak, J. O. Park, M. Srinvasarao, and U. H. F. Bunz: Advanced Materials 16 (2004) 115.

9) L. V. Govor, I. A. Bashmakov, F. N. Kaputski, M. Pientka, and J. Parisi: Macromolecular Chemistry and Physics 201 (2000) 2721.

10) Y. Tian, S. Liu, H. Ding, L. Wang, B. Liu, and Y. Shi: Polymer 48 (2007) 2338

11) Y. Xu, B. Zhu, and Y. Xu: Polymer 46 (2005) 713.

12) O. Pitois and B. Francois: Colloid Polymer Science 277 (1999) 574.

13) H. Yabu, M. Kojima, M. Tsubouchi, S. Onoue, M. Sugitani, and M. Shimomura: Colloids and Surfaces A 284-285 (2006) 254.

14) X. Zhao, Q. Cai, G. Shi, Y. Shi, and G. Chen: J. Appl. Polymer Science 90 (2003) 1846

15) O. Pitois and B. Francois: The European Physical Journal B 8 (1999) 225.

16) J. Peng, Y. Han, J. Fu, Y. Yang, and B. Li: Maclomolecular Chemistry and Physics 204 (2003) 125.

17) B. Francois, Y. Ederle, and C. Mathis: Synthetic Metals 103 (1999) 2362.

18) J. Ping, H. Xiao-Yong, Y. Hong, and G. Qi-Huang: Chinese Physical Letters 23 (2006) 1813.

19) A. Tsuruma, M. Tanaka, N. Fukushima, and M. Shimomura: e-Journal of Surface Science and Nanotechnology 3 (2005) 312.

20) H. Yabu, M. Tanaka, N. Fukushima, and M. Shimomura: Langmuir 21 (2005) 3235.

21) Y. Hirai, H. Yabu, and M. Shimomura: Colloids and Surfaces A 313-314 (2008) 312.

22) S. Matsushita, R. Fujiwara, and M. Shimomura: Colloids and Surfaces A 313-314 (2008) 617.

23) M. Tanaka, K. Nishikawa, H. Okubo, H. Kamachi, T. Kawai, M. Matsushita, S. Todo, and M. Shimomura: Colloids and Surfaces A 284-285 (2006) 464.

24) H. Sunami, E. Ito, M. Tanaka, S. Yamamoto, and M. Shimomura: Colloids and Surfaces A 284-285 (2006) 548.

25) Y. Fukuhira, H. Kaneko, M, Yamaga, M. Tanaka, S. Yamamoto, and M. Shimomura: Colloids and Surfaces A 313-314 (2008) 520.

26) K. Arai, M. Tanaka, S. Yamamoto, and M. Shimomura: Colloids and Surfaces A 313-314 (2008) 530.

27）レーザー学会：レーザーハンドブック(オーム社，2005)。

28) E. O. Hulburt: Journal of the Optical Society of America 35 (1945) 698.

29）大塚徳勝：そこが知りたい物理学, (共立出版, 1999).

30) A. Benuzzi, T. Lower, M. Koenig, B. Faral, D. Batani, D. Beretta, C. Danson, and D. Pepler: Phys. Rev. E 54 (1996) 2162. 